\title{
Democratic Policy in Europe
}

\author{
Fritz W. Scharpf*
}

\begin{abstract}
This article examines the implications of European integration for democratic self-determination. Distinguishing between the dimensions of 'autonomy' and 'effectiveness', it is argued that autonomous processes of democratic participation, public discourse and democratic accountability have not yet been established on the European level. On the other hand, the effectiveness of democratic self-determination at the national level is increasingly constrained by processes of economic globalisation and even more so by the completion of the European internal market. At the same time, however, conflicts of interest among the Member States of the European Union often stand in the way of effective European problem-solving in those areas where the nation-state is losing control. It is argued, therefore, that it would be desirable to allow greater legal scope to national policy choices by limiting the reach of 'negative integration' and European competition law in those areas where the Union itself, for political reasons, is incapable of effective action.
\end{abstract}

\section{Introduction}

In comparison with the first post-war decades, politics in Europe has lost much of its capacity for democratic self-determination. The European Union in its present form constitutes in some respects part of the problem and in other respects part of the possible solution; in important areas it is neither one thing nor the other. If we are to arrive at a realistic, pragmatically useful assessment of the possible reforms that might at best be reached in the Maastricht II negotiations, these aspects should be clearly distinguished. In order to do so, this article will concentrate on clarifying the basic structures of the issues and some conceivable solutions.

The normative criterion underlying the arguments to be developed herein is democratic self-determination, seen as the capacity of citizens of a given community to attain common objectives and solve common problems by collective action. This capacity is never absolute, and two conceptually independent criteria are relevant in analysing it: greater or lesser autonomy of decision-making, and greater or lesser effectiveness of action towards the objectives chosen. While these criteria are logically independent, the possibility of empirical connections is not to be ruled out. In particular, a negative connection may arise, if, for instance, the effectiveness of political action can only be enhanced by shifting decisional competence to a level at which autonomous democratic decision-making is barely possible.

* Director, Max-Planck-Institut für Gesellschaftsforschung, Cologne. This text was translated by Iain L. Fraser. A German version was published in (1995) 4 Staatswissenschaften und Staatspraxis 565. 


\section{Autonomy: The Democratic Deficit Cannot Be Reformed Away}

Democratic autonomy implies that political decisions should proceed directly or indirectly from the free and equal involvement of all citizens, with more direct forms of involvement generating more legitimacy than less direct ones. Democratic autonomy is accordingly stronger with a plebiscite than with a parliamentary act; it is stronger with this latter than with decisions of the executive appointed by and responsible to parliament. Again, it is stronger with unanimous decisions than with bare majorities, and it is stronger in unitary systems with a clear allocation of decisional competence and political responsibilities than when decisions are produced by the 'horizontal' or 'vertical' collaboration of representatives with separate bases of legitimation. Accordingly, for example, the federal 'joint decision-making' in the Federal Republic of Germany undoubtedly comes at the expense of reduced parliamentary control and therefore of political autonomy ${ }^{1}$.

However, unitary legitimation of majority decisions is not an available option under any and all conditions. It presupposes the existence of a 'community' with a collective identity, which implies that in regard to particular issues citizens are in principle prepared to treat their fellow citizens' interests as their own. It is only where this is the case that the minority need not fear exploitation, oppression or annihilation by the ruling majority ${ }^{2}$; and it is only where this is the case that measures amounting to redistribution at the expense of individual interests will be considered acceptable ${ }^{3}$. In short, it is only where solidarity on the basis of collective identity can be presumed to exist in principle among all concerned that a minority can be asked to respect majority decisions despite disagreement over important issues.

These prerequisites for the unitary legitimation of majority decisions are not met at any level above that of the nation-state; they do not exist in the European Union, and it will become more and more difficult to create them as the expansion of the Union increases the ethnic, cultural and economic heterogeneity of its Member States and thus reduces the possibility of forming an identity ${ }^{4}$. Even enhanced legislative and budgetary powers for the European Parliament, considered the primary remedy for the 'democratic deficit' in European politics, can do very little to change much in this respect. Accordingly, the European Union remains dependent on indirect legitimation

' Scharpf, 'The Joint Decision Trap: Lessons from German Federalism and European Integration', (1988) 66 Public Administration 239.

${ }^{2}$ Even then, the legitimation of majority decisions vis-à-vis the outvoted minority requires further institutional safeguards. Among these are constitutional protection of life, health, liberty and property, and the generality of the law. This is not an external restriction of the majority's will but the internal prerequisite for its normative binding power. Why should I have to obey the law if it could be used by the majority to destroy me?

${ }^{3}$ There is undoubtedly also a universal human solidarity against death, illness and extreme poverty. But one need only compare the extent of West-East redistribution in the German nation-state (some 6 per cent of the Gross Domestic Product) with the German contribution to development aid (less than 0.4 per cent of the Domestic Product) in order to see the de facto importance of a historically specific collective identity for redistributional solidarity. Thus, whatever one's position may be with regard to the philosophical dispute between universalism and communitarianism, for practical politics the second position has more weight. See J. Habermas, Faktizität und Geltung. Beiträge zur Diskurstheorie des Rechts und des Rechtsstaats (Suhrkamp, 1992).

${ }^{4}$ Kielmansegg, 'Läßt sich die Europäische Union demokratisch verfassen?', in W. Weidenfeld (ed), Reform der Europäischen Union. Materialien zur Revision des Maastrichter Vertrages 1996 (Verlag Bertelsmann Stiftung, 1994) 229. 
of its decisions through the 'horizontal' cooperation of democratically elected national governments in the Council of Ministers and the European Council. Because of the unavoidable diffusion of political responsibility, this form of legitimisation is weaker on the whole than unitary, democratic legitimation, and even then the argument only strictly applies to decisions taken by unanimous vote.

For a country whose government is outvoted in the Council, the majority decision means not self-rule but subjection to foreign rule. This may be accepted for higher purposes, in consideration of the long-term, politically desirable advantages of EU membership. However, the more important the outvoted national interests are in the individual case, the weaker the legitimation of European decisions will certainly be. In terms of democratic theory, therefore, there are good reasons giving support to the present practice of the Council, at the insistence of France against the text of the treaties, of allowing Member States a veto, even in decisions to be taken by qualified majority, if 'essential interests' of the country would otherwise be violated. The Union's 'democratic deficit' would become even more virulent to the extent that this practice were given up in favour of simple majority decisions in the Council or in the European Parliament. The implication, however, is that any further 'deepening' of the Union will for the foreseeable future encounter objections deriving from democratic theory, which cannot simply be defined away by mere constitutional reforms ${ }^{5}$. The conclusion seems inevitable, therefore, that the democratic autonomy of political decisions is progressively weakened as more and more decisional powers are transferred from national to European level.

Thus, if democratic self-determination were to be defined exclusively in terms of autonomy, one could readily conclude, in accordance with the juridical syllogisms of the German Constitutional Court's Maastricht decision, that the democratic deficit of the European Union cannot be overcome in the foreseeable future. But if democracy is to be more than a social-therapeutic exercise to satisfy basic human needs for genuine participation, the debate cannot ignore the dimension of effective problem-solving. Democratic self-determination, to be sure, cannot be equated with illusions of omnipotence. Like mature individuals, mature democracies have learned to live with constraints. Nevertheless, the meaning of self-determination is to shape the collective fate of the polity in response to the considered preferences of the body politic. Thus, where the effectiveness of democratically legitimated political choices tends towards zero, so too democracy comes to an end. Therefore the fact that European integration is the subject of controversial debate in terms of democratic theory at all (and not just as a threat to democratic legitimacy) can only be explained by the hypothesis that the effectiveness of democratic fate-control is eroding at the national level, but may perhaps be recovered at the European level. On closer consideration, however, the first clause in this hypothesis has rather more empirical evidence supporting it than has the hope contained in the second part of the phrase. A differentiated approach is accordingly required.

${ }_{5}^{5}$ This is not meant to deny the usefulness of constitutional reforms, see W. Weidenfeld (ed), Europe ' 96. Reforming the European Union. Strategies for Europe (Bertelsmann Foundation Publishers, 1994). In particular, the political legitimacy of Commission decisions (which are extremely important, de facto and $d e$ jure) would be greatly increased if the President were elected by, and politically accountable to, the European Parliament, and if the Commission were selected and presented by the President for confirmation by the Council and by the Parliament. This would greatly help to focus public attention, and hence the interest of political parties, on European-wide issues. 


\section{Effectiveness: National Policy in the Global Capital Market}

The nation-state remains to date the most comprehensive political unit in which autonomous democratic decision-making seems possible. Yet the possibility of effective self-determination in a national framework is becoming increasingly uncertain. Self-determination ideally presupposes congruence between those participating in democratic decisions and those affected by them. In so far as democratically governed units are territorially demarcated, this implies that the effects of national decisions should remain confined to the constituency in question and that the attainment of national objectives depends on factors which may be manipulated using the resources of the nation-state. The effectiveness of democratic selfdetermination is thus constrained by the fact that the domain of the state has boundaries. At the same time, a great variety of transnational interaction effects escape the state's direct control. Global communications are influencing national cultures; global terrorism and global criminality are endangering internal security; global migration is changing the composition of the population; global pollution is jeopardising the quality of life, and the list could easily be extended. But nothing affects the effectiveness of democratic self-determination so fundamentally as the embeddedness of the national economy in the world economy.

The democratic state developed in historical symbiosis with the capitalist economy. While the economy is dependent on the state's legal system and infrastructure, the state is dependent on stable tax revenues. Governments are held accountable by their voters for maintaining the economic foundations of their existence. At the same time, however, the capitalist economy tends toward global integration; it is prone to recurrent crises, it generates negative externalities and unequal distribution. Democratic governments for their part are committed to stability, distributive justice and environmental protection; they must thus seek to contain the capitalist dynamic of 'creative destruction'. This presupposes that the border-crossing interaction effects in the economy can be brought under control. In its logical conclusion, therefore, the democratic ideal would be most completely realised in the economically autarkic territorial state, which, however, would have to forego all the advantages of the international division of labour, remaining thus technically backward and economically underdeveloped.

The symbiosis between the democratic state and the intrinsic dynamics of the international capitalist economy has therefore always been a precarious one. While democratic politics is primarily driven to action by crises on the labour market and on commodity markets, the control function of the capitalist economy lies in the capital market, and it is the conditions prevailing on this market which determine investment, output and ultimately employment. At the same time, capital is the internationally most mobile factor and can most easily evade state controls. Capital markets were de facto fully internationalised under the gold standard and were freed of all national control before the First World War, and again in the 1920s; the influence of state policy on the crisis cycles of the capitalist economy was correspondingly slight. This constellation collapsed, however, in the world economic crisis of the 1930s. Under the inexorable political pressure of mass unemployment, states everywhere began to defend themselves against global capitalism. The German Reich's autarky policy pursued in preparation for war was admittedly an extreme case, but all countries were seeking to protect domestic production by competitive devaluation, high customs barriers and imports quotas, while at the same time preventing the outflow of 
investment capital by comprehensive controls on capital movements. The outcome was not only the destruction of the open world market but a drastic fall in the level of prosperity.

However, it was from that very destruction of the world economy that the 'Great Transformation' 6 emerged which, in the post-war decades, permitted the democratic civilisation of the capitalist economy. Because national economies were now walled off from each other through effectively controlled borders, national policy could employ 'Keynesian' tools to dampen macroeconomic cycles, while at the same time building up efficient systems of social security and redistribution. The basis of full employment policy was the control of capital movements, which allowed national interest-rate policy to vary the minimum rate of return that capital investors could expect if they opted for interest-bearing financial assets instead of job-creating real investments. At the same time, control over foreign trade created conditions under which domestic suppliers could shift the costs of national social policy or environmental regulations onto consumers without being undersold by foreign competitors. It was because of this control by the nation-state of its own borders that, in the post-war decades, the capitalist economy was able to flourish as much in the political context of the extremely costly Swedish welfare state as in the German social market economy or in the American free-enterprise system.

The gradual reintegration of the world economy did not at first alter these conditions. On the contrary, the regulatory systems internationally agreed under American leadership supported and strengthened national capacities. The Bretton Woods system of fixed exchange rates gave protection against the temptation to competitive devaluations; the International Monetary Fund enabled temporary payment-balance deficits to be bridged; and in the event of lasting competitive imbalances, exchange rates could still be adjusted. Similarly, on commodity markets, the series of GATT negotiations drawn out over decades only gradually reduced tariff walls and other barriers to trade, thereby facilitating national adjustment strategies and allowing for various exceptions where crises nonetheless arose in individual sectors of the economy. In brief, in contrast to the uncontrolled international capitalism of the pre-war period, the 'embedded liberalism' of international economic regimes made it possible in the post-war decades to benefit from the advantages of the international division of labour without destroying the capacity of nation-states to shape their internal economic and social order ${ }^{7}$.

These conditions no longer exist today, most importantly because since the early 1970s governments have lost control over capital markets. The system of fixed exchange rates broke down because the United States had exploited the dollar's position as official reserve currency for the inflationary financing of the Vietnam War, thus feeding the extraterritorial 'Euro-dollar markets's. The move to floating exchange rates opened the door to currency speculation, controls on capital movements lost their effectiveness and, in the wake of the oil price crises, not only Third World countries but also Western industrial states became increasingly dependent on the international capital markets. In consequence, the interest level on this market henceforth determined the rate of return for investment-seeking capital. This had two

${ }^{6}$ K. Polanyi, The Great Transformation (Beacon Press, 1957).

${ }^{7}$ Ruggie, 'International Regimes, Transactions, and Change: Embedded Liberalism in the Postwar Economic Order', (1982) 36 IO 379.

${ }^{8}$ Calleo, 'America's Federal Nation State: A Crisis of Post-imperial Viability', (1994) 42 Political Studies 319. 
important consequences. National monetary policy lost the capacity to increase the relative attractiveness of real investments by cutting interest rates. National interest rates below the international level no longer create more jobs but merely drive capital out of the country. Thus the tools of Keynesian full employment policy lost their effectiveness in a national context ${ }^{9}$. At the same time, all nation-states are now in competition with each other for highly mobile international investment capital, and accordingly endeavour to offer capital investors the most attractive terms possible. Because of this competition, marginal tax rates were cut drastically in one country after another during the $1980 \mathrm{~s}^{10}$, and for the same reason more and more countries are hesitating to actually collect taxes on capital incomes that continue to exist legally. Thus the globalisation of capital markets, a practically irreversible process, has again quashed the national control over the capitalist economy that had been achieved in the post-war period ${ }^{11}$. In short, 'Polanyi's Great Transformation is over'12.

\section{Negative and Positive Integration in Europe}

The European Community had little to do with the globalisation of capital markets, even if the series of exchange-rate coordination schemes established 'on the sidelines' of the Community reduced the transaction costs for firms (and improved the competitiveness of the German economy) in inter-European trade ${ }^{13}$. The major emphasis of European policy was on the integration of markets for goods and services. In that regard, even the original treaties of 1957 went far beyond the GATT objectives, and the 1986 Single European Act adopted the much more radical commitment to create a 'European internal market' in which all national barriers to the 'free movement of goods, persons, services and capital' would be removed by 31 December 1992.

Essentially, that commitment was also realised. By comparison with the cumbersome progress of world market integration in GATT and now the WTO, the purposive advancement of European economic integration is indeed remarkable. It is due primarily to the fact that the obligation on Member States to remove national barriers to trade and to refrain from competition-distorting measures was interpreted by the Commission and the European Court of Justice as directly applicable 'supranational' law that overrides the laws and constitutions of Member States, and that this interpretation was also accepted by national courts and applied in domestic cases. That this outcome was by no means a matter of course, but rather requires

${ }^{9}$ F. W. Scharpf, Crisis and Choice in European Social Democracy (Cornell University Press, 1991).

10 Steinmo, 'The End of Redistribution? International Pressures and Domestic Policy Choices', (1994) Challenge, November-December, 9.

11 Ruggie, 'At Home Abroad, Abroad at Home: International Liberalization and Domestic Stability in the New World Order', Jean Monnet Chair Papers, no 20 (European University Institute, 1995).

12 Cerny, 'The Dynamics of Financial Globalization: Technology, Market Structure, and Policy Response', (1994) 27 Policy Sciences 339.

13 Since German inflation rates were generally below those of its partner countries, while exchange-rate adjustments were often delayed for political reasons, all variants of European monetary regimes tended to undervalue the German mark and thus promote German exports. If the European Monetary Union (in which long-term differences in competitiveness could no longer be compensated, even by delayed devaluations) were not paradoxically promoted chiefly by France and against German resistance, it would surely be rejected as a plot of German economic imperialism. 
explanation, has only recently been perceived, and particularly by American jurists ${ }^{14}$. What matters here is the fact that these rules of 'negative integration' can be enforced, without involvement of the Council of Ministers, the European Commission, the European Court of Justice and national courts. This is true in particular for European competition law which, in the words of the commissioner initially responsible for its implementation, was not only meant 'to prevent firms from abusing their market power, but also to eliminate distortions of competition resulting from differences among the legal and administrative rules of Member States or from differences of their legal or fiscal policy'15.

To fully appreciate this remarkable feat of interpretation, one must realise that this supranational European competition law was derived from the terse wording of treaties concluded by states whose own competition law, except for Germany, provided hardly any effective remedies against market-dominating firms. Nowhere, moreover, would it have been possible to rely on competition law to strike down 'legal and administrative rules' of the state itself. Not even in Germany, after all, had the neoliberal idea of an 'economic constitution' found the support of the Constitutional Court, and neither could German cartel legislation claim superiority over any other measures which the legislature considered appropriate on economic or social policy grounds ${ }^{16}$. In Europe, however, the 'cunning of the idea' ${ }^{17}$ has given legal primacy to neo-liberal postulates over the constitutions, statutes and established institutions of Member States ${ }^{18}$.

'Negative integration' rules out all national measures and existing regulations that might be capable of restricting the freedom of the border-crossing movement of goods, persons, services and capital, or of distorting free and equal competition between domestic and foreign suppliers or demanders. At national level, thus, European integration amounts to a twofold, de jure and de facto, compulsion to deregulate. Legally, existing regulations will be invalidated to the extent that they can be interpreted as discriminating against foreign suppliers producing at their home location under different legal regimes. But if all foreign suppliers must be admitted to national markets, governments will come under pressure to remove, or avoid, burdensome regulations which act as a de facto discrimination against domestic suppliers. Moreover, since in the completed internal market domestic suppliers also have the option to shift production to more favourable locations without endangering

14 See Weiler, 'The Community System. The Dual Character of Supranationalism', (1981) 1 YEL 257; Weiler, 'A Quiet Revolution. The European Court of Justice and its Interlocutors', (1994) 26 Comparative Political Studies 510; Burley and Mattli, 'Europe before the Court: A Political Theory of Legal Integration', (1993) 47 IO 41; Mattli and Slaughter, 'Law and Politics in the European Union. A Reply to Garrett', (1995) 49 IO 183.

$15 \mathrm{H}$. von der Groeben, Deutschland und Europa in einem unruhigen Jahrhundert. Erlebnisse und Betrachtungen (Nomos, 1995), pp 343ff.

16 Joerges, 'Markt ohne Staat? Die Wirtschaftsverfassung der Gemeinschaft und die regulative Politik', in R. Wildenmann (ed), Staatswerdung Europas? Optionen für eine Europäische Union (Nomos, 1991) 225.

17 A. Müller-Armack, Wirtschaftsordnung und Wirtschaftspolitik. Studien und Konzepte zur sozialen Marktwirtschaft und zur europäischen Integration (Rombach, 1964) 405.

18 Behrens, 'Die Wirtschaftsverfassung der Europäischen Gemeinschaft', in G. Brüggemeier (ed), Verfassungen für ein ziviles Europa (Nomos, 1994) 73; Mestmäcker, 'Zur Wirtschaftsverfassung in der Europäischen Union', in R. H. Hasse, J. Molsberger and C. Watrin (eds), Ordnung in Freiheit. Festgabe für Hans Willgerodt zum 70. Beburtstag (Gustav Fischer, 1994) 263; Mestmäcker, 'Über das Verhältnis der europäischen Wirtschaftsordnung zu den Mitgliedstaaten', (1994) Veröffentlichungen der Joachim Jungius-Gesellschaft 77, 149. 
their access to the domestic market, negative integration brings about a 'regulatory competition' among European Community Member States which, if nothing else happens, will 'open the door wide to a pure laissez-faire capitalism'19.

Even the neo-liberal founding fathers of the European Community had not intended such a development ${ }^{20}$. The EEC Treaty allowed at least the continued existence of national import restrictions that could be justified 'on grounds of public morality, public policy or public security, protection of health and life of humans, animals or plants; ... or ... industrial and commercial property' (Article 36). Further, in order not to have the common market fail for that reason, the Treaty also from the outset opened up the possibility of 'positive integration' through legal harmonisation and re-regulation at European level. Positive integration, however, cannot be brought about through interpretations of the Treaty by the Commission and the Court acting in isolation. It depends on political action by the Council of Ministers and the European Parliament. Since the 1966 Luxembourg compromise made only unanimous decisions possible on the Council, and since the Commission in its proposals for harmonising national legal and administrative provisions exceeded them if anything in level of detail, procedures for legal harmonisation proved extremely cumbersome and inefficient. Market integration accordingly advanced only slowly.

This changed with the 1986 Single European Act, which not only set the magic date of 31 December 1992 for the completion of the internal market, but also simplified and speeded harmonisation procedures by having the Council henceforth decide only the principles of safety requirements, leaving the elaboration of detailed rules to 'corporatist' standardisation bodies. Moreover, for the harmonisation decisions needed to complete the internal market, a return to decision by qualified majority was accepted (Article 100a (1)). Eliminating the veto has considerably speeded the procedure, although most decisions are still taken unanimously ${ }^{21}$.

\section{Competitive Deregulation in the Completed Internal Market}

In the upshot, and against many sceptical expectations, the internal market programme has proved to be a self-fulfilling prophecy. The nearly 300 harmonisation decisions considered essential were adopted more or less on schedule, and even before 1992 firms had adjusted their location decisions and investment and production plans to the fact that in future national borders would no longer play a determining part in the production and marketing of goods and services. This de facto development, sparked off by the internal market programme, once again radically worsened the conditions for political effectiveness of national policy.

With the globalisation of capital markets, nation-states in principle lost the possibility of taxing internationally mobile finance capital more heavily than in 'tax havens'. Yet domestic firms could still be sure of having to deal, at least on the domestic market, only with competitors that produced under approximately the same regulatory conditions. Shifts of production abroad might have been necessary for reasons of market access, but for competition on the domestic market they were of

\footnotetext{
19 von der Groeben, 'Probleme einer europäischen Wirtschaftsordnung', in J. F. Baur, P. Müller-Graff and M. Zuleeg (eds), Europarecht, Energierecht, Wirtschaftsrecht. Festschrift für Bodo Börner (Carl Heymanns, 1992) 123.

20 Müller-Armack, op cit n 17, p 243.

21 Dehousse and Weiler, 'The Legal Dimension', in W. Wallace (ed), The Dynamics of European Integration (Pinter, 1990) 242.
} 
relatively slight importance. This changed fundamentally with the completion of the internal market. While product-related regulations are largely harmonised or must be mutually recognised, and legal provisions in the area of production-related regulation of environment protection and worker protection are to some extent unified (though not necessarily their implementation), this is not true of those regulations that primarily affect location-specific production costs. These include collectivelybargained wages, working hours, sick-pay rules, social-security levies and taxes, codetermination, production-related environmental protection and many other factors that add to the costs of production.

Obviously, some of these differences in the costs of production are compensated by a variety of positive location factors, the availability of skilled workers, more or less 'cooperative'industrial relations, the quality and reliability of the public infrastructure or the availability of high-grade services. But even if the balance of country-specific costs and locational advantages should be in equilibrium in every country, the terms of trade between government and trade union policy on the one hand and firms on the other have been changed because of the fact that Daimler-Benz can now supply the German market just as well from Lorraine as from Sindelfingen, or that Siemens can manufacture the new chip generation just as efficiently in Britain as in Saxony. The point here is not that shifts of production actually occur, but that they can now take place without difficulty. Nor is it important that the terms offered elsewhere should be better all round. Even if the overall burden were the same everywhere, firms have gained a strategic advantage by their new freedom of choice among national systems of regulations.

Assuming that all national governments and unions must try to keep production and jobs at home, the European mobility of firms forces them into a competition in which national packages of burdens and benefits will be unpacked as each specific locational disadvantage in comparison with another country becomes a separate issue in national debates. The outcome is that Member States and unions will be forced into much further-reaching concessions to firms than would have been conceivable before the completion of the internal market.

Admittedly, there are important differences here among the various methods of 'system competition' being played out in the internal market. The Treaty itself subjects state aid to strict control by the Commission and the Court (Articles 92-94) in order to make sure that locational competition should not degenerate into a subsidisation race. Similarly, while the successive models of the European Monetary System have to date intended to offer protection against competitive devaluations, the future European Monetary Union will completely rule out that possibility. By contrast, trying to achieve locational advantages through competitive deregulation, tax cuts and reductions of non-wage labour costs is apparently not considered objectionable in competition theory, and the treaties accordingly give neither the Commission nor the Court the power to intervene against unilateral national action of this kind. Under the pressure of increasing competition, all Member States have accordingly made astonishing progress over the last decade in the direction of deregulation, flexibilisation of labour markets and the reduction of taxes and other cost burdens on firms, yet the pressure does not abate, since other countries, acting under the same pressure, are similarly struggling to improve their locational conditions. Thus if, say, Germany is debating a reduction in social-security levies paid by firms, it is a matter of course that France will have already done so, and other countries will have to follow suit in lightening the burden on their firms. Competitive deregulation in the internal 
market is a game that no country can hope to win, but from which none is able to withdraw unilaterally.

The outcome is first of all a shift in the costs of the welfare state from mobile to immobile cost bearers ${ }^{22}$. After the reduction of marginal income tax rates, there is now a need to reduce the burden on firms from levies and regulations that raise production costs. To compensate, the burden on labour income, private consumption ${ }^{23}$ and private ownership of land increases. This primarily hits lower-middle-class voters who depend on income from work, who consume the major part of that income and whose assets are essentially confined to their own home. Since, however, in competitive democracies no party can remain long in government without the support of the lower middle class, their fast-growing tax resistance must ultimately be taken seriously. If, then, capital incomes, firms and mobile professionals cannot be taxed more heavily for economic reasons, nor middle incomes taxed more heavily for political reasons, then the outcome to be expected in weak political systems (like Belgium or Italy) is an uncontrollable rise in national indebtedness. In stronger political systems, by contrast, there will be, sooner (as in Britain) or later (as in Germany or France), expenditure cuts in all areas not directly affecting international competitiveness: defence policy, development aid, cultural, educational, health, environment, research, and social welfare policy. The expectable consequence is the dismantling of state services and social benefits, poorer public infrastructure, greater social inequality and a rapid increase in the population living below the poverty line ${ }^{24}$. Many countries are at present having to fight all of these problems at once, and the malaise of the 1980s and 1990s everywhere can in principle be traced back to the fact that nation-states have lost control over their own frontiers.

\section{European Reregulation?}

But if this is so, why can the problem not be handled by that very European Union whose internal market programme, going far beyond GATT obligations, contributed so largely to intensifying it? The Union, to be sure, is not now, nor will it be in the future, in a position to make changes in the globalisation of capital markets. Whatever European coordination or a European Central Bank might be able to do here has already been done by the German Bundesbank. But this is not and cannot be enough, for there is an astounding disproportion between the currency reserves available to the Bundesbank (or to any other central bank) and the astronomical volume of funds transferred around the globe on any single day in search of minute profits ${ }^{25}$. Against speculative avalanches of that order of magnitude, a European Central Bank would be no less helpless than are the national banks, and it is perhaps significant that banking

\footnotetext{
22 Sinn, 'The Taming of Leviathan. Competition among Governments', (1993) 3 Constitutional Political Economy 177.

23 In this connection it is fortunate that no agreement was reached on plans to change from the country-of destination principle to the country-of-origin principle for the collection of the value-added tax. Thus, national governments remain free, for the time being, to shift part of the financial burden of the welfare state from non-wage labour costs to consumption.

${ }^{24}$ One might describe the overall effect of locational competition as follows: it benefits the recipients of capital incomes and the consumption of marketed goods and services. It hurts recipients of social incomes and the consumption of goods and services that are not (sufficiently) supplied by the market.

${ }^{25}$ Cerny, op cit $\mathrm{n} 12$.
} 
circles expect increased flight, rather than better control, as a consequence of the European Monetary Union' ${ }^{26}$.

But on the markets for goods and services, Europe is much more important for most suppliers in Member States than the world market, and with regard to the European market, production locations on Union territory are clearly privileged. While the Union has introduced radical free trade in the internal market, its dealings with the outside world show that it does not merely remain a fortress of agricultural protectionism but is at least as ready as the United States to exploit all the GATT options in the industrial sphere to protect suffering industries and to intervene against oversuccessful competitors by means of anti-dumping measures and bilaterally-agreed quantitative restrictions. In short, European protectionism remains an option, and changes of government in Britain or Germany might be enough to turn the option practised in exceptional cases into the dominant European strategy.

At any rate, even today the full intensity of locational competition is restricted to locations within the European internal market. In principle, common European regulations could thus still subject all firms in direct competition to the same regulatory regime. In that regard, therefore, the capacity for civilising the capitalist economy that was lost at the national level might perhaps be regained at the European level. It is the hope for this second 'Great Transformation' which inspires the 'Europeans' in social democratic parties and trade unions, and it seems to have been the same hope that inspired the internal market programme conceived by Jacques Delors as well as the Single European Act of 1986. Nor have these hopes been completely disappointed. The internal market programme, after all, has not just broken down national frontiers, it also brought a host of common European safety and environmental regulations for consumer products and work places ${ }^{27}$. If, however, deep 'Euro-pessimism' is now setting in, particularly on the left of the political spectrum and in the unions, this is due to the intensified repercussions of European locational competition on those policy areas that are not covered by European harmonisation. These include environmental regulations that would significantly increase the production costs of internationally exposed industries, as well as the whole area of social security and redistribution. In these areas, there is scarcely any common European policy, and it is precisely here that locational competition is being fought out, with all its destructive consequences for the social welfare and industrial relations systems built up over the decades. Two reasons can be given for the de facto absence of European regulations to limit locational competition.

One comes from the basic conflict of interests between the more highly industrial and the less developed Member States of the Union. The competitiveness of the former is based on their impressive labour productivity, which has so far allowed them to impose both high wages and high social and environment costs on firms. Because of far lower average productivity of jobs in countries of the second group, both wage and non-wage labour costs and environment costs for firms must be considerably lower if

${ }^{26}$ Perina, 'Zweifel am inneren Wert. Europäische Währungsunion: Sparer sind zunehmend verunsichert. Banken erwarten eine Kapitalflucht', DIE ZEIT, 1.9.1995, 26.

27 Eichener, 'Social Dumping or Innovative Regulation? Processes and Outcomes of European DecisionMaking in the Sector of Health and Safety at Work Harmonization', Working Papers in Political and Social Science, no 28 (European University Institute, 1992); Eichener and Voelzkow, 'Ko-Evolution politischadministrativer und verbandlicher Strukturen: Am Beispiel der technischen Harmonisierung des europäischen Arbeits-, Verbraucherund Umweltschutzes', in W. Streeck (ed), Staat und Verbände. PVS Sonderheft 25/1994, 256. 
they are to survive in European competition. Unitary European rules which meet the level of expectations, and the ability and willingness to pay for them, in Denmark, Germany or the Netherlands would thus destroy the competitiveness of the local industries in Portugal, Greece or Spain in a European market, just as industry in East Germany was destroyed when West German regulations and West German wages were imposed. Conversely, unitary rules at an economically acceptable level for Portugal would not meet either environmental needs or social expectations in the most highly developed countries.

If that were all the problems amounted to, the obvious solution would be the introduction of two-level regulations, and it would be surprising that political debate had not long been focused on that. If the high-productivity countries could set joint rules among themselves at a high level of protection, while the low-productivity countries similarly agreed on joint rules at a lower level, that would in principle benefit both groups. Since the locational advantages of the highly productive countries are balanced out by their higher costs and those of the low-cost countries by their lower productivity, it may be seen that the most damaging locational competition on wages, social welfare costs and environmental regulations takes place among countries producing at more or less the same level of productivity. In selecting a location for the production of the Swatch car, Daimler-Benz did not decide between Germany and Greece, but between Baden-Württemberg and Lorraine; and for Siemens's new chip production, the choice fell on Britain, not Portugal. To stop this form of ruinous competition, it would thus be sufficient for the high-cost countries, and similarly for the low-cost countries, to agree on condition-cartels among themselves. Unitary regulations for the whole Union would then not only be politically unfeasible, but they would also be neither necessary nor desirable.

If two-level regulations of this sort are not seriously debated in the European Union, this is not simply because of the passion for uniformity that has characterised European policy from the outset, nor is it merely a tribute to the political sensitivities that any reference to a 'two-speed Europe' arouses in countries that might not belong to the inner circle. There is also no reason to think that technical, legal obstacles should be decisive: in Maastricht I, Britain's 'opting out' allowed the other Member States to go ahead with the 'Social Charter' among themselves, using the available machinery of binding European regulations for the purpose. The solution which then seemed legally practicable for the Eleven could also be made to serve the purposes of separate, but legally effective, agreements among groups of five or seven Member States.

More serious difficulties would arise from differing interests or ideological positions within the group of highly developed countries (that would primarily have to push for two-level solutions). The present British government, for instance, seems to assume that Britain might win a deregulation race in Europe, thus achieving important locational advantages. Other governments, including perhaps the German government, need the pressure of European locational competition in order to impose a minimum of deregulation and flexibilisation, considered desirable for other reasons, despite domestic political resistance. In short, one may doubt the initial assumption that all high-cost countries in the Union ought to have a common interest in European regulations that protect their present social welfare and industrial relations systems against locational competition in the internal market.

But if changes of government in Germany and Britain were to strengthen the forces that have an interest in defending the welfare state, two-level regulations would still 
encounter major obstacles. They result from the institutional differences among the national solutions which were accentuated, behind controlled frontiers, in the post-war decades. In health, for instance, there is scarcely anything in common between the British National Health Service, funded from general taxation and budget-controlled on the expenditure side, and the German health care system which is funded by corporatist systems of compulsory insurance and controlled through fee-for-service allotments on the expenditure side ${ }^{28}$. As regards old-age pensions, there are similar differences between the 'Scandinavian' model of tax-funded basic pensions for all combined with contribution-based supplementary payments and the 'continental' model of corporatist systems of compulsory insurance providing earnings-related pensions on a pay-as-you-go basis ${ }^{29}$.

Even greater are the differences among European industrial relations systems. In the Scandinavian countries, Austria and Germany, collective bargaining for wages and work conditions is generally highly centralised, involving industrial unions with a representational monopoly for large sectors of the economy. In the Latin countries, by contrast, there are typically several competing unions differing in their ideological orientations and party-political affiliations. In Britain, finally, there is not only a much larger number of unions, many of them representing individual occupations, but collective bargaining is also much more decentralised. The obstacles to a common European approach to wage bargaining that arise from this institutional diversity can scarcely be overestimated ${ }^{30}$. In addition, there are enormous differences in the relationship between the industrial relations system and the legal system of the state $^{31}$. On the one hand, there is the British tradition of 'free collective bargaining' which, since the turn of the century, has avoided governmental or judicial intervention, relying exclusively on the relative bargaining strength of unions and employers for the settlement of disputes. At the other extreme, there is the 'legalistic' German tradition of precisely regulated collective bargaining at the level of the industry, institutionalised codetermination at the level of the firm, and pervasive, court-enforced labour law governing the individual employment contract. It tends to provide better protection than the British system against fluctuations in union bargaining strength in the vicissitudes of the economy, but it is also much more dependent on fluctuations of legislation and judge-made law. This is why, as the Directive on European works councils has shown, unitary European regulations of industrial relations are bound to encounter great difficulties, even among trade unions, so that the default outcome will often conform to the employers' overt dislike for any kind of European regulation.

The number of examples could be multiplied, but the argument is clear: institutional differences among the high-cost countries are particularly marked in the social welfare systems and in industrial relations. They are also associated with the existence of influential large organisations which, in their defence of the institutional status quo, are likely to have the political support not only of their own large workforces but also of their clients and their interest organisations. The more

\footnotetext{
28 J. Alber and B. Bernardi-Schenkluhn, Westeuropäische Gesundheitssysteme im Vergleich: Budesrepublik Deutschland, Schweiz, Frankreich, Italien, Großbritannien (Campus, 1992).

29 G. Esping-Andersen, The Three Worlds of Welfare Capitalism (Polity Press, 1990).

30 Ebbinghaus and Visser, 'Barrieren und Wege "grenzenloser Solidarität": Gewerkschaften und Europäische Integration', in W. Streeck (ed), Staat und Verbände. PVS Sonderheft 25/1994, 223.

31 C. Crouch, Industrial Relations and European State Traditions (Clarendon Press, 1993).
} 
comprehensive social welfare systems have become, the more difficult is any form of restructuring ${ }^{32}$.

Paradoxically, it is therefore more likely that the economic compulsions of locational competition will make each high-cost country seek its own salvation in deregulation and social dismantling than that there will be agreement on uniform European regulations at present levels of protection. While the hardship associated with the former solution will seem to be legitimated by external necessity, any attempt at a European harmonisation of national welfare state systems would not only have to cut more deeply into institutionalised interest positions and expectations, but would also create winners and losers among the countries involved, depending on which of the national models a joint solution would be based upon. Even in environmental policy, the 'regulatory competition' among divergent national administrative traditions has been a major obstacle to agreement on European-wide regulations ${ }^{33}$, the difficulties would become insuperable if European harmonisation were to mean not only changes in administrative routines but also a restructuring or elimination of historically developed and powerful institutions in health, old-age provision and industrial relations.

\section{Ways Out?}

The chances for regaining democratic effectiveness at European level are thus certainly not favourable. From the perspective of democratic theory, this means first of all that there is little reason to take the greater problem-solving capacity of European policy as a compensatory argument against the European democratic deficit in the dimension of autonomous democratic decision-making. The democratic legitimation of European policy is and remains weak in comparison with the legitimation of democratic constitutional states. It also follows that, regardless of the constructs of international law, the 'supranational' primacy of European law over national law appears as an anomaly in constitutional theory: the more weakly legitimated law is supposed to override the better legitimated one. In this regard, the oft-criticised decisions of the German Federal Constitutional Court on the relationship between the Basic Law and the European Union may also appear as an expression of the normative ambivalence of this relationship.

This does not mean, however, that the re-nationalisation of policy might offer a more positive outlook. In order to have any effect, it would need to employ protectionist measures that would be in clear violation of treaty obligations. But transnational economic integration has now gone so far in Europe that escalating national protectionisms would not just mean the end of the Union, it would also plunge the European economy into catastrophic straits. At best, protectionism would have an economic chance at European level, and for that very reason locational competition would not be removed within Europe. But with the end of the nation-

32 Obviously, it is not only institutional self-interest that stands in the way of restructuring, but also objective barriers. For instance, the move from pensions based on the inter-generational contract in the German system to a 'Scandinavian' system of a tax-funded basic pension and 'savings-based' additional payments, which is often called for, would mean that the generation now working would have to pay twice - once for present pensioners and again for their own supplemental pension.

33 A. Héritier, S. Mingers, C. Knill and M. Becka, Die Veränderung von Staatlichkeit in Europa. Ein regulativer Wettbewerb: Deutschland, Großbritannien und Frankreich in der Europäischen Union (Leske \& Budrich, 1994). 
state, does it follow that we have now come to the 'end of democracy'34, and that politics is no longer able to confront the anonymous rule of worldwide markets with the deliberate choices of citizens acting in democratic association?

The danger indeed exists, and it is all the greater, the less recognition is given to the fundamental shifts that have taken place in the politico-economic environment, and the more the expectations of the post-war decades are maintained. The compulsion to adopt convergent policies delegitimates national politics. While democratic selfdetermination is not to be equated with the fulfilment of each and every wish, it does imply freedom and therefore the possibility of choice ${ }^{35}$. But if henceforth national economic policy can only amount to deregulation, flexibilisation and cost reduction, then democracy has also lost its function of securing acceptance for political choices that could go one way or the other. The democratic process would then lose its link to policy choices and would degenerate into a media show with no legitimising significance. Policies so produced could no longer count on norm-based voluntary compliance. They would undermine the unquestioned acceptance of state authority and of solidarity obligations. The result would not only be general political disaffection and alienation, but a cynical readiness to exploit the resources of the community while shirking concomitant obligations. Indications of this can already be seen in many countries. Much is therefore at stake if politics at European level cannot act while politics at national level has lost its effectiveness. The only means of avoiding this horror scenario is to employ the limited possibilities of action at both levels, national and European, in such a way that the existing but limited opportunities for effective policy at both levels are exploited and predictable frustrations sidestepped. This has important implications for the relationship between European and national policy.

\section{A European Two-Level Politics}

By embodying the subsidiarity principle in the Treaty, Maastricht made an attempt to stem the expansion of European competencies which, evidently, many felt had gone too far. However, as the clause has little legal effect, it does no direct harm ${ }^{36}$. Yet the debate on subsidiarity has focused exclusively on the distribution of powers between the national and the European levels, as if this were a zero-sum conflict. It thus detracts attention from the much more important issue of whether, in the face of the market forces unleashed, the capacity for effective political action can be maintained at any level. At a minimum it would thus be necessary to avoid scenarios in which national policy is prevented by European law from tackling a particular problem on its own, while at the European level conflicts of interest rule out effective solutions. Under present politico-economic conditions, European nations can no longer afford these self-created policy deficits in their multilevel political system. They could be avoided if the existing asymmetry between negative and positive integration ${ }^{37}$ were removed.

\footnotetext{
34 J-M. Guéhenno, La fin de la démocratie (Flammarion, 1993).

35 Luhmann, 'Kausalität im Süden', (1995) 1 Soziale Systeme, 7.

36 Dehousse, 'Does Subsidiarity Really Matter?', EUI Working Paper Law No 92/32 (European University Institute, 1993).

37 Scharpf, 'Negative and Positive Integration in the Political Economy of European Welfare States', Jean Monnet Chair Papers, no 28 (European University Institute, 1995).
} 
This situation arises, as we have seen, from the fact that the 'negative' interventions against national restrictions on competition can be derived from the 'primary Community law' of the Treaties themselves, and can accordingly be applied by the Commission and the courts alone, while the 'positive' acts of European policy remain dependent on the agreement of the governments in the Council. In the early decades of the Economic Community, when the common market had to be initially established against existing national trade barriers, that may have made a lot of sense. By now, however, the internal market has become a reality, and the harmonisation of productrelated standards necessary for its completion has come about. We now have a substantial body of 'secondary Community law', which is quite sufficient to guarantee the free movement across national borders of capital, goods, services and persons. It is true of course that this body of secondary Community law is unevenly developed. Product-related standards are almost complete, and rules on work safety and productrelated environmental protection have been harmonised in large part, while the process for industrial relations and social welfare regulations has so far hardly advanced at all, and can hardly advance, for the reasons mentioned. Nor is this likely to change. Where agreement is possible, the regulations are now in place, and where no European rules exist at present, they are lacking not because they were found to be unnecessary, but because each country is trying to push through a different solution.

This could form a strong argument for a basic revision of the allocation of functions between Union and Member States in the treaties, and for a return to Member States of those tasks for which agreement has not been achieved so far and is unlikely to be achieved in the future. Thus, for instance, the fact that the mandate to develop a 'common transport policy' (Articles 74-84 EEC) that was contained in the original text of the Treaty has not yet been fulfilled after almost 40 years could lead one to draw the conclusion that this area ought to be explicitly left to Member States. The same could apply to energy policy or media policy. Of course, for all these areas, to which others could be added, there are more or less plausible functionalist or economic arguments for the transfer of regulatory powers to the European level. In the Union's present position, however, these arguments count for little in comparison to the political criterion of whether the capacity for consensual action does, or does not, exist at the European level. Where basic conflicts of interest among Member States block agreement, the Union should leave responsibility for the policy area as a whole (i.e. including its competition-law aspects) to the individual Member States.

A further important step is taken with the suggestion that it should no longer be possible to derive directly applicable restrictions on Member State action from the primary law of the treaties. Such an argument can be based on an analogy to the constitutional development in the United States. Just like the European Court of Justice, the American Supreme Court had for decades limited the regulatory powers of the individual states through the 'negative commerce clause doctrine', derived directly from the Constitution, where their exercise was seen as interfering with the freedom of commerce across state lines. But when the 'positive' regulatory powers of the federal government were finally recognised in the 1937 constitutional revolution, the 'negative commerce clause' case law was abandoned. State measures have since been struck down only when they are directly in conflict with a Congressional statute; but where Congress has refrained from positive regulation, the powers of individual states are no longer constitutionally restricted by the commerce clause.

Clearly, the American model could not be transplanted to Europe without modification. In contrast to the US Constitution, the primary Community law also 
contains very precise and detailed regulations, the characteristics of which correspond more to the level of a statute than to that of a constitution. But in the context of a fundamental revision of the treaties, there would nevertheless be good reasons for a 'separation between a constitution-like basic treaty and a detailed implementing treaty containing the technical details ${ }^{38}$. The implementing treaty might then contain those regulations which, according to the political will of the contracting states, should continue to be directly applicable as secondary European law. The basic treaty, by contrast, should regulate the international-law obligations of Member States as well as the competencies of the Union and its organs, the applicable procedures, and the civilrights limitations on the exercise of European powers. This 'lean' basic treaty could not be used by either the Commission, the European Court or national courts to directly interfere with national legislation. At the same time, drafting the implementing treaty would provide a welcome opportunity for governments to review the extent of directly applicable Treaty law in the light of existing interpretation by the Commission and Court in order to ascertain whether it still corresponds with the current intent of the members of this unique Community of States. In this fashion, some of the excesses in the case law on negative integration might be corrected, and constitutional anomalies, such as the Commission's power to issue general directives under Article 90(3) EC without the involvement of Council and Parliament, might be removed.

\section{B European Rules to Limit Locational Competition}

Admittedly, these legal changes would not be able to remove the economic compulsions of locational competition, but they might at least avoid scenarios in which the regulatory powers of nation-states are legally constrained even though the European Union either will not or cannot act. Beyond that, however, the Union could also help to regulate the locational competition in which Member States find themselves entrapped as a consequence of the internal market. From the abovesaid, however, it follows that this cannot be achieved through Europe-wide and uniform regulations. It is true that the basic conflict of interests between economically highly productive countries with expensive social welfare systems and economically less developed countries whose competitiveness depends on lower labour, social and environment costs might in principle be overcome by regulations at different levels of protection. But given the institutional differences among the group of high-cost countries, their consensus on uniform regulations in the area of social welfare and industrial relations would be most unlikely.

If, then, there should be a social-policy cartel among the high-cost countries, the conditions need to be formulated in institutionally neutral terms. As a stop-gap measure, one might consider a temporary ban on measures to reduce existing levels of social-policy protection while longer-term common rules are being developed. These rules might then set lower limits (perhaps defined by reference to GDP, and rising progressively with per-capita GDP) for a country's total financial expenditure on social welfare systems (sickness, old age, unemployment) without prescribing the organisational form, funding methods or division between transfer benefits and social services. Above this minimum level of expenditure, of course, reforms and innovations would continue to be possible and desirable at the national level. In other areas where

38 Weidenfeld, op cit $\mathrm{n} 5$. 
direct financial expenditure is not an appropriate measure of regulatory intensity, one might contemplate applying a rule to national measures of deregulation and welfare cutbacks phrased in analogy to the prohibition, in Article 92 of the Treaty, of state aid 'which distorts or threatens to distort competition by favouring certain undertakings or the production of certain goods'. Obviously, there would be difficult lines to draw, but if it is possible for the Commission and the Court to distinguish legitimate subsidies from those that distort competition, then the same ought also to be possible for the distinction between competitively neutral and competition-distorting deregulation. It might even be expected that the explicit parallel drawn between competitive deregulation and competition-distorting subsidies might also help to make the case law on subsidies more sensitive to the need for national room to manoeuvre in economic policy.

\section{New European Tasks}

Beyond that, the present constitutional debate ought also to be directed at enhancing the capacity of European policy to act in those areas where frustration at Member States' inability to act is reaching politically dangerous dimensions. In light of Europe's performance in the Yugoslav civil war, this is today most critical in the areas of foreign and security policy. European integration has from the outset suffered from the fact that, with the failure of the European Defense Community, the organisation of this central area of common concern had to be left entirely to NATO. From the perspective of European states, national defence was so essential to the core idea of national sovereignty that military forces and strategies, though they could be coordinated in a classical alliance, could not be transferred to a supranational body. This has not changed much in the meantime.

In the former Yugoslavia, however, national defence was not the issue in any sovereignty-relevant sense. Instead, what was at stake was the capacity of Western European governments to pursue essentially common interests against the outside world through effectively concerted action. If there is a parallel here, it is to foreign trade policy. In other words, what is at stake is the production of a collective good which, as is well-known in theory ${ }^{39}$, is extremely difficult to bring about by voluntary cooperation. Thus NATO was and is dependent on the leading role of the American hegemony, and the history of out-of-area operations has shown that it is unable to act if the United States, after weighing its own interests, will not or cannot assume the leadership function. This emerged clearly in the peace-making and peace-keeping attempts in the former Yugoslavia.

But let us suppose, on a purely hypothetical level, that a separate European intervention force had been in operation in 1989, funded from the EU budget, organised as a 'foreign legion' on the French model, well-equipped and under the supreme command of a Commission President elected by, and politically accountable to, the European Parliament. It is hard to conceive that under these conditions too, the rather marginal differences between the foreign policy preferences of Germany, France and Britain could have completely crippled European policy, and that the Union could have failed so disastrously in its essential role of maintaining order in Europe. In short, I consider it feasible that just as Union leadership is now accepted as

${ }^{39}$ M. Olson, The Logic of Collective Action (Harvard University Press, 1965); Olson and Zeckhauser, 'An Economic Theory of Alliances', (1966) 48 Review of Economics and Statistics 266. 
a matter of course in external trade policy, so also military out-of-area policy may now be ripe for Europeanisation. If $\mathrm{I}$ am right here, a latent common interest is waiting to become institutionalised. All that should be needed is to demarcate this task clearly enough from national defence, which should continue to remain primarily a national responsibility. It should also be added that the high visibility and political salience of foreign and security policy could immensely speed up the formation of a common European political identity, which could in turn legitimate more effective governing structures in other policy areas as well.

Put more abstractly, then, the point is to accept, and act on, the insight that for the time being Europe has a capacity for effective action only in those areas where the interests of the Member States clearly converge. Any attempt to assign to the European Union problems and tasks on which agreement is precluded by fundamental conflicts of interest among the Member States can only deepen political frustration in Europe. It follows that where Europe cannot act, the capacity for political action at the national level must be protected or restored, if the democratic legitimation of policy at all levels is not to be undermined. Conversely, however, there is also every reason to transfer powers to the Union in areas where Europe could act while the national governments on their own are unable to.

\section{Bibliography}

J. Alber and B. Bernardi-Schenkluhn, Westeuropäische Gesundheitssysteme im Vergleich: Budesrepublik Deutschland, Schweiz, Frankreich, Italien, Großbritannien (Campus, 1992)

Behrens, 'Die Wirtschaftsverfassung der Europäischen Gemeinschaft', in G. Brüggemeier (ed), Verfassungen für ein ziviles Europa (Nomos, 1994) 73

Burley and Mattli, 'Europe before the Court: A Political Theory of Legal Integration', (1993) 47 International Organization, 41

Calleo, 'America's Federal Nation State: A Crisis of Post-imperial Viability', (1994) 42 Political Studies 319

Cerny, 'The Dynamics of Financial Globalization: Technology, Market Structure, and Policy Response', (1994) 27 Policy Sciences 319

C. Crouch, Industrial Relations and European State Traditions (Clarendon Press, 1993)

Dehousse, 'Does Subsidiarity Really Matter?', EUI Working Paper Law No 92/32 (European University Institute, 1993)

Dehousse and Weiler, 'The Legal Dimension', in W. Wallace (ed), The Dynamics of European Integration (Pinter, 1990)

Ebbinghaus and Visser, 'Barrieren und Wege "grenzenloser Solidarität": Gewerkschaften und Europäische Integration', in W. Streeck (ed), Staat und Verbände. PVS Sonderheft 25/1994, 223

Eichener, 'Social Dumping or Innovative Regulation? Processes and Outcomes of European DecisionMaking in the Sector of Health and Safety at Work Harmonization', Working Papers in Political and Social Science, no 28 (European University Institute, 1992)

Eichener and Voelzkow, 'Ko-Evolution politischadministrativer und verbandlicher Strukturen: Am Beispiel der technischen Harmonisierung des europäischen Arbeits-, Verbraucherund Umweltschutzes', in W. Streeck (ed), Staat und Verbände. PVS Sonderheft 25/1994, 256

G. Esping-Andersen, The Three Worlds of Welfare Capitalism (Polity Press, 1990)

J-M. Guéhenno, La fin de la démocratie (Flammarion, 1993)

J. Habermas, Faktizität und Geltung. Beiträzur Diskurstheorie des Rechts und des Rechtsstaats (Suhrkamp, 1992)

A. Héritier, S. Mingers, C. Knill and M. Becka, Die Veränderung von Staatlichkeit in Europa. Ein regulativer Wettbewerb: Deutschland, Großbritannien und Frankreich in der Europäischen Union (Leske \& Budrich, 1994)

Joerges, 'Markt ohne Staat? Die Wirtschaftsverfassung der Gemeinschaft und die regulative Politik', in R. Wildenmann (ed), Staatswerdung Europas? Optionen für eine Europäische Union (Nomos, 1991) 
Kielmansegg, 'Läßt sich die Europäische Union demokratisch verfassen?', in W. Weidenfeld (ed), Reform der Europäischen Union. Materialien zur Revision des Maastrichter Vertrages 1996 (Verlag Bertelsmann Stiftung, 1994)

Luhmann, 'Kausalität im Süden', (1995) 1 Soziale Systeme 7

-Mattli and Slaughter, 'Law and Politics in the European Union. A Reply to Garrett', (1995) 49 International Organization 183

Mestmäcker, 'Zur Wirtschaftsverfassung in der Europäischen Union', in R. H. Hasse, J. Molsberger and C. Watrin (eds), Ordnung in Freiheit. Festgabe für Hans Willgerodt zum 70. Beburtstag (Gustav Fischer, 1994) 263

Mestmäcker, 'Über das Verhältnis der europäischen Wirtschaftsordnung zu den Mitgliedstaaten', (1994) Veröffentlichungen der Joachim Jungius-Gesellschaft 77

A. Müller-Armack, Wirtschaftsordnung und Wirtschaftspolitik. Studien und Konzepte zur sozialen Marktwirtschaft und zur europäischen Integration (Rombach, 1964)

M. Olson, The Logic of Collective Action (Harvard University Press, 1965)

Olson and Zeckhauser, 'An Economic Theory of Alliances', (1966) 48 Review of Economics and Statistics 266

K. Polanyi, The Great Transformation (Beacon Press, 1957)

Ruggie, 'International Regimes, Transactions, and Change: Embedded Liberalism in the Postwar Economic Order', (1982) 36 International Organization 379

Ruggie, 'At Home Abroad, Abroad at Home: International Liberalization and Domestic Stability in the New World Order', Jean Monnet Chair Papers, no 20 (Florence: European University Institute, 1995)

Scharpf, 'The Joint Decision Trap: Lessons from German Federalism and European Integration', (1988) 66 Public Administration 239

F. W. Scharpf, Crisis and Choice in European Social Democracy (Cornell University Press, 1991)

Scharpf, 'Negative and Positive Integration in the Political Economy of European Welfare States', Jean Monnet Chair Papers, no 28 (European University Institute, 1995)

Sinn, 'The Taming of Leviathan. Competition among Governments', (1993) 3 Constitutional Political Economy 177

Steinmo, 'The End of Redistribution? International Pressures and Domestic Policy Choices', (1994) Challenge, November-December 9

von der Groeben, 'Probleme einer europäischen Wirtschaftsordnung', in J. F. Baur, P. Müller-Graff and M. Zuleeg (eds), Europarecht, Energierecht, Wirtschaftsrecht. Festschrift für Bodo Börner (Carl Heymanns, 1992)

H. von der Groeben, Deutschland und Europa in einem unruhigen Jahrhundert. Erlebnisse und Betrachtungen (Nomos, 1995)

W. Weidenfeld (ed), Europe '96. Reforming the European Union. Strategies for Europe (Bertelsmann Foundation Publishers, 1994)

Weiler, 'The Community System. The Dual Character of Supranationalism', (1981) 1 YEL 257

Weiler, 'A Quiet Revolution. The European Court of Justice and its Interlocutors', (1994) 26 Comparative Political Studies 510 